\title{
A 46-Year Retrospective Study of Oral Vascular Anomalies in a Brazilian Population
}

\author{
Estudio Retrospectivo de 46 Años de Anomalías \\ Vasculares Orales en una Población Brasileña
}

\begin{abstract}
Úrsula Costa"; Amanda Katarinny Goes Gonzaga²; Denise Hélen Imaculada Pereira de Oliveira; Tiago João da Silva Filho ${ }^{4} \&$ Lélia Maria Guedes Queiroz ${ }^{5}$
\end{abstract}

COSTA, U.; GONZAGA, A. K. G.; OLIVEIRA, D. H. I. P.; SILVA FILHO, T. J. \& QUEIROZ, L. M. G. A 46-year retrospective study of oral vascular anomalies in a Brazilian population. Int. J. Odontostomat., 15(1):248-255, 202.

ABSTRACT: A retrospective study was performed to describe the demographic and clinicopathological characteristics of cases of vascular anomalies in a Brazilian population. The data of cases diagnosed as vascular anomalies over a period of 46 years, were retrieved from the archives of the Pathological Anatomy Service of the Department of Dentistry of Federal University of Rio Grande do Norte. Information about sex, age, race, diagnosis, location, and clinical characteristics was extracted. A database was created for analysis in the SPSS system and description of the results. The sample consisted of 597 cases categorized as follows: pyogenic granuloma $(n=454)$, infantile hemangioma $(n=57)$, vascular malformation ( $n$ = 37), lymphangioma $(n=20)$, hemangiolymph angioma $(n=10)$, vascular thrombus $(n=7)$, hemangio endothelioma $(n=$ $5)$, angiofibroma $(n=1)$, hemangioendothelio sarcoma $(n=1)$, and Kaposi sarcoma $(n=5)$. Overall, there was a predominance of females $(64.2 \%)$, white race $(54.2 \%)$, and patients in the $3 \mathrm{rd}$ and 4 th decades of life. Most cases affected the gingiva/ ridge $(44.75 \%)$, had a red/reddish color $(60.07 \%)$, sessile implantation $(52.4 \%)$, soft consistency $(52.7 \%)$ and nodular appearance $(53,9 \%)$, and were non-hemorrhagic (51.3\%) and asymptomatic (76.6 \%). The demographic and clinicopathological findings obtained for most of the vascular lesions analyzed are similar to those reported in published studies involving other populations. Knowledge of the particularities of these disorders is important for appropriate diagnosis and treatment decision.

KEY WORDS: vascular anomalies, hemangioma, epidemiology.

\section{INTRODUCTION}

Vascular anomalies (VAs) are congenital or acquired lesions whose predominant components are vascular structures. This group currently includes all congenital malformations of the vascular system (VMs) - capillary, venous, lymphatic, arterial and combinations; benign vascular tumors such as infantile hemangioma $(\mathrm{IH})$ and malignant vascular tumors such as angiosarcoma and Kaposi sarcoma, as well as pyogenic granuloma (PG), a non-neoplastic proliferative reactive lesion (Mulliken \& Glowacki, 1982; Enjolras et al., 2007; Gordón-Núñez et al., 2010a).
As a result of their similar clinical and histological features, the lack of internationally accepted diagnostic standardization in relation to the terminology and classification of VAs has hindered adequate therapeutic indications for some time. Treatments are often applied in a heterogenous and non-standardized manner, increasing the risk of iatrogenic events such as unnecessary mutilation resulting from the surgical treatment of regressing lesions that would only require follow-up or treatment failure and unnecessary expenditures in cases of surgical indication (Hiraki \& Goldenberg, 2010; Hassanein et al., 2011).

\footnotetext{
${ }^{1}$ Student, Postgraduate Program in Public Health, Faculty of Health Sciences of Trairi, Federal University of Rio Grande do Norte, Santa Cruz, RN, Brazil.

2 Professor, Department of Dentistry, Federal University of Rio Grande do Norte, Natal, RN, Brazil.

${ }^{3}$ Professor, Department of Dentistry, Federal University of Ceará, Sobral, CE, Brazil.

${ }^{4}$ Professor, Department of Dentistry, State University of Paraíba, Campina Grande, PB, Brazil.

${ }^{5}$ Professor, Postgraduate Program in Oral Pathology, Department of Dentistry, Federal University of Rio Grande do Norte, Natal, RN, Brazil.
} 
In 1996, the International Society for the Study of Vascular Anomalies (ISSVA) created a classification standard based on the biological behavior and clinical features of these disorders. However, some authors continued to generically classify different lesions of vascular origin as "hemangioma" (Enjolras et al.). Due to the persistence of the problem with the nomenclature of the VAs, the ISSVA after the last Workshop in Melbourne, Australia (2014), and in an attempt to achieve a uniform classification, decided to incorporate some changes and update the classification. That classification, which was approved and well accepted after the 20th ISSVA Workshop, and last revised on May 2018 (the interactive document is available at www.issva.org), classifies VAs as vascular tumors (benign, locally aggressive or borderline, and malignant) and vascular malformations (simple, combined, of major named vessels, and associated with other anomalies) (ISSVA Classification of Vascular Anomalies, 2018).

Epidemiological knowledge of VAs may aid in the correct diagnosis, but studies on the prevalence and clinical features of these disorders are still sparse. We therefore performed a retrospective analysis of VAs registered at the Oral Pathology Service of the Department of Dentistry of Federal University of Rio Grande do Norte, Brazil, in a 46-years period of time, already classified according to the ISSVA proposal, describing their frequency, demographic peculiarities and clinicopathological characteristics and comparing the results to those of studies involving other populations (da Silva Filho et al., 2017).

\section{MATERIAL AND METHOD}

The study was approved by the Ethics Committee of University Federal of Rio Grande do
Norte (Approval No. 1.817.173). This was a descriptive study in which a sample of 597 cases of vascular lesions diagnosed at the Oral Pathology Service, Department of Dentistry, Federal University of Rio Grande do Norte, over a period of 46 years was analyzed.

All cases registered as oral vascular lesions whose records contained demographic data of the patients (sex, race, and age) and characteristics of the lesion (location, color, implantation, consistency, appearance, bleeding, symptoms, and diagnosis) were included. After the verification of the clinical records, the results were organized in a computerized table to facilitate understanding of the data, tabulated, and exported to the SPSS ${ }^{\circ} 20.0$ program for descriptive analysis.

\section{RESULTS}

Over the period studied, 14,560 soft and hard tissue lesions were registered at the service. Histology confirmed VAs in 597 of these cases, corresponding to an incidence of $4.1 \%$. The benign VAs identified were PG $(n=454)$, IH $(n=57)$, VMs $(n=37)$, lymphangioma $(n=20)$, hemangiolymphangioma $(n=$ $10)$, vascular thrombus $(n=7)$, hemangioendothelioma $(n=5)$, and soft tissue angiofibroma $(n=1)$ (Fig. 1). Kaposi sarcomas $(n=5)$ were the locally aggressive or borderline vascular tumors identified and only one case of angiosarcoma representing the malignant vascular tumors. (Table I).

Analysis of the sociodemographic profile of the patients showed a female predilection $(n=383,64.2$ $\%)$. There was a predominance of white patients $(48.2$ $\%)$, followed by brown (24.6\%), black (14.9\%) and other patients $(1.17 \%)$. Hemangioendothelioma,
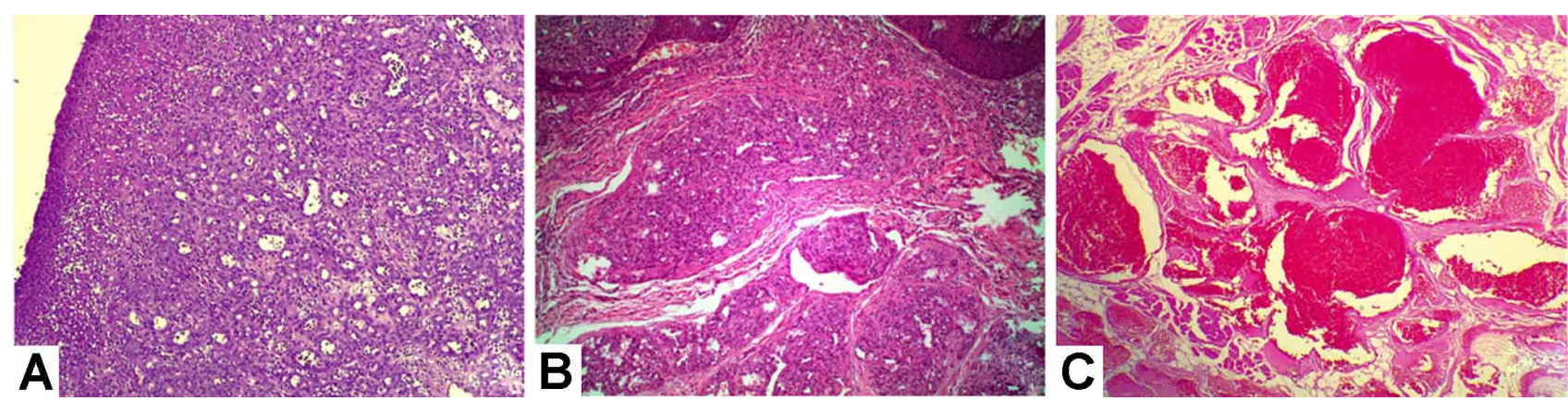

Fig. 1. Photomicrograph showing histopathological characteristics (Hematoxylin / Eosin) of the VAs most present in the current study: (A) PG, (B) HI, (C) VM. (ADVANCE; 400x). 
Table I. Frequency of oral vascular anomalies recorded in the Service of Pathological Anatomy of the Department of Dentistry of Federal University of Rio Grande do Norte, 2019.

\begin{tabular}{lll}
\hline LESION BENIGN & $\mathrm{N}$ & $\%$ \\
Pyogenic granuloma & 454 & $76,00 \%$ \\
Infantile hemangioma & 57 & $9,50 \%$ \\
Vascular malformation & 37 & $6,20 \%$ \\
Lymphangioma & 20 & $3,40 \%$ \\
Hemangiolynphangioma & 10 & $1,70 \%$ \\
Vascular Thrombus & 7 & $1,20 \%$ \\
Angiofibroma & 1 & $0,20 \%$ \\
$\begin{array}{l}\text { BORDELINE VASCULAR } \\
\text { Kaposi Sarcoma }\end{array}$ & 5 & $0,80 \%$ \\
MALIGNANT & & \\
Hemangioendothelioma epithelioid & 6 & $1,00 \%$ \\
TOTAL & 597 & $100 \%$ \\
\hline
\end{tabular}

angiosarcoma and Kaposi sarcoma were only detected in men (Table II). A wide age range was affected, with most patients being in the second, third and fourth decades of life. The largest differences between minimum and maximum age were observed for $P G$, $\mathrm{IH}$ and hemangiolymphangioma (Table II).

The most commonly affected anatomical site was the gingiva/alveolar ridge (42.9\%), probably because the samples mainly consisted of PGs. The gingiva/alveolar ridge was also the most common site in the case of angiofibroma and hemangioendothelioma. The remaining lesions were more frequent in the lip (18.2
$\%)$, palate $(12.0 \%)$, cheek mucosa $(8.7 \%)$, and tongue $(7.5 \%)$ (Table III).

With respect to particularities of VAs, most lesions had a red color ( $n=304,50.9 \%$ ), followed by the normal color of the mucosa $(n=92,15.4 \%)$, purple/purplish $(n=32,5.4 \%)$, blue $(n=29,4.8 \%)$, white $(n=25,4.2$ $\%)$, and other $(n=24,4.0 \%)$. However, the blue category was the most common among hemangiolymphangiomas $(n=3)$ and vascular thrombi $(n=4)$ (Table IV).

Sessile implantation was the most frequent type (42.0\%), although the pedunculated type was more common (38.2 \%) among PGs $(n=206)$ and the only angiofibroma was also a pedunculated tumor. Most lesions had soft consistency (44.5\%), but the fibrous type was more common among VMs ( $\mathrm{V}=18)$, hemangiolymphangioma $(n=6)$, hemangioendothelioma $(n=2)$, and Kaposi sarcoma $(n=3)$. There was a predominance of nodular appearance (38.3 \%), followed by lobulated lesions (26.8 \%). Most VAs were non-hemorrhagic (45.2\%) and asymptomatic (32.8\%) (Table IV).

Comparison of the clinical and histopathological diagnosis described in the records showed that $27.9 \%$ ( $n=167$ ) of the lesions were diagnosed clinically as other non-vascular diseases (e.g., fistula, mucocele, papilloma, cyst, leukoplakia, ameloblastoma). An incorrect clinical diagnosis was found in $37.5 \%(n=224)$ of the cases (Table V).

Table II. Distribution of the frequency of sex, age and race of oral vascular anomalies registered at the Service of Pathological Anatomy of the Department of Dentistry of the Federal University of Rio Grande do Norte, 2019.

\begin{tabular}{|c|c|c|c|c|c|c|c|c|c|c|c|}
\hline \multicolumn{12}{|c|}{ VASCULAR LESIONS (n) TOTAL } \\
\hline & $\begin{array}{l}P G \\
(n)\end{array}$ & $\begin{array}{l}\mathrm{IH} \\
(\mathrm{n})\end{array}$ & $\begin{array}{l}\text { VM } \\
\text { (n) }\end{array}$ & $\begin{array}{l}\text { LINP } \\
(\mathrm{n})\end{array}$ & $\begin{array}{l}\mathrm{HL} \\
(\mathrm{n})\end{array}$ & $\begin{array}{l}\text { VT } \\
(n)\end{array}$ & $\begin{array}{l}\mathrm{HE} \\
(\mathrm{n})\end{array}$ & $\begin{array}{l}\mathrm{AF} \\
(\mathrm{n})\end{array}$ & $\begin{array}{l}\mathrm{KS} \\
(\mathrm{n})\end{array}$ & $\mathrm{N}$ & $\%$ \\
\hline \multicolumn{12}{|l|}{ SEX } \\
\hline Female & 303 & 35 & 21 & 21 & 7 & 4 & 0 & 1 & 0 & 383 & 64.2 \\
\hline $\begin{array}{l}\text { Male } \\
\text { RACE }\end{array}$ & 151 & 22 & 16 & 16 & 8 & 3 & 5 & 0 & 5 & 214 & 35.8 \\
\hline White & 219 & 34 & 15 & 10 & 4 & 2 & 2 & 1 & 1 & 288 & 48.2 \\
\hline Brown race & 111 & 12 & 14 & 5 & 3 & 1 & 0 & 0 & 1 & 147 & 24.6 \\
\hline Black & 69 & 6 & 4 & 1 & 1 & 2 & 3 & 0 & 2 & 89 & 14.9 \\
\hline Others & 5 & 0 & 1 & 1 & 0 & 0 & 0 & 0 & 0 & 7 & 1.17 \\
\hline $\begin{array}{l}\text { Missing } \\
\text { AGE }\end{array}$ & 50 & 5 & 3 & 3 & 2 & 2 & 0 & 0 & 1 & 66 & 11.0 \\
\hline Mínimum & 2 & 1 & 17 & 8 & 7 & 29 & 10 & 11 & 21 & 572 & 95.8 \\
\hline Maximum & 77 & 824 & 804 & 81 & 82 & 73 & 57 & 11 & 39 & & \\
\hline Médium & 32,4 & 0,4 & 8 & 39,1 & 47,5 & 54,5 & 29,6 & 11 & 31,6 & & \\
\hline Missing & 21 & 2 & 0 & 1 & 0 & 1 & 0 & 0 & 0 & 25 & 4.2 \\
\hline
\end{tabular}

PG: Pyogenic granuloma; IH: Infantile hemangioma; VM: Vascular malformation; LINP: Lymphangioma; HL: Hemangiolymphangioma; VT: Vascular trombus; HE: Hemangioendothelioma; AF: Angiofibroma; KS: Kaposi sarcoma; Missing: lost cases; n: numbe rof cases; \%: Percentage. 
Table III. Distribution by anatomical location of oral vascular anomalies recorded in the Service of Pathological Anatomy of the Department of Dentistry of the Federal University of Rio Grande do Norte, 2019.

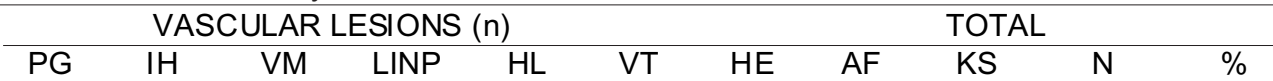

$(n) \quad(n) \quad(n) \quad(n) \quad(n) \quad(n) \quad(n) \quad(n) \quad(n)$

\begin{tabular}{|c|c|c|c|c|c|c|c|c|c|c|c|}
\hline \multicolumn{12}{|l|}{ LOCATION } \\
\hline Gingiva/ Ridge & 237 & 8 & 3 & 1 & 0 & 0 & 3 & 1 & 2 & 256 & 42.9 \\
\hline Lip & 63 & 18 & 14 & 8 & 3 & 3 & 0 & 0 & 0 & 109 & 18.2 \\
\hline Palate & 43 & 12 & 7 & 3 & 3 & 1 & 1 & 0 & 2 & 72 & 12.0 \\
\hline Oral mucosa & 30 & 8 & 9 & 1 & 2 & 2 & 0 & 0 & 0 & 52 & 8.7 \\
\hline Tongue & 63 & 4 & 3 & 6 & 1 & 0 & 0 & 0 & 1 & 45 & 7.5 \\
\hline Other & 29 & 5 & 1 & 1 & 1 & 1 & 0 & 0 & 0 & 38 & 6.4 \\
\hline Missing & 22 & 2 & 0 & 0 & 0 & 0 & 1 & 0 & 0 & 25 & 4.3 \\
\hline
\end{tabular}

PG: Pyogenic granuloma; IH: Infantile hemangioma; VM: Vascular malformation; LINP: Lymphangioma; HL: Hemangiolymphangioma; VT: Vascular trombus; HE: Hemangioendothelioma; AF: Angiofibroma; KS: Kaposi sarcoma; Missing: lost cases; n: number of cases; \%: Percentage.

Table IV. Distribution of clinical characteristics (color, implantation, consistency, aspect, symptomatology) of oral vascular anomalies registered at the Service of Pathological Anatomy of the Department of Dentistry of the Federal University of Rio Grande do Norte, 2019.

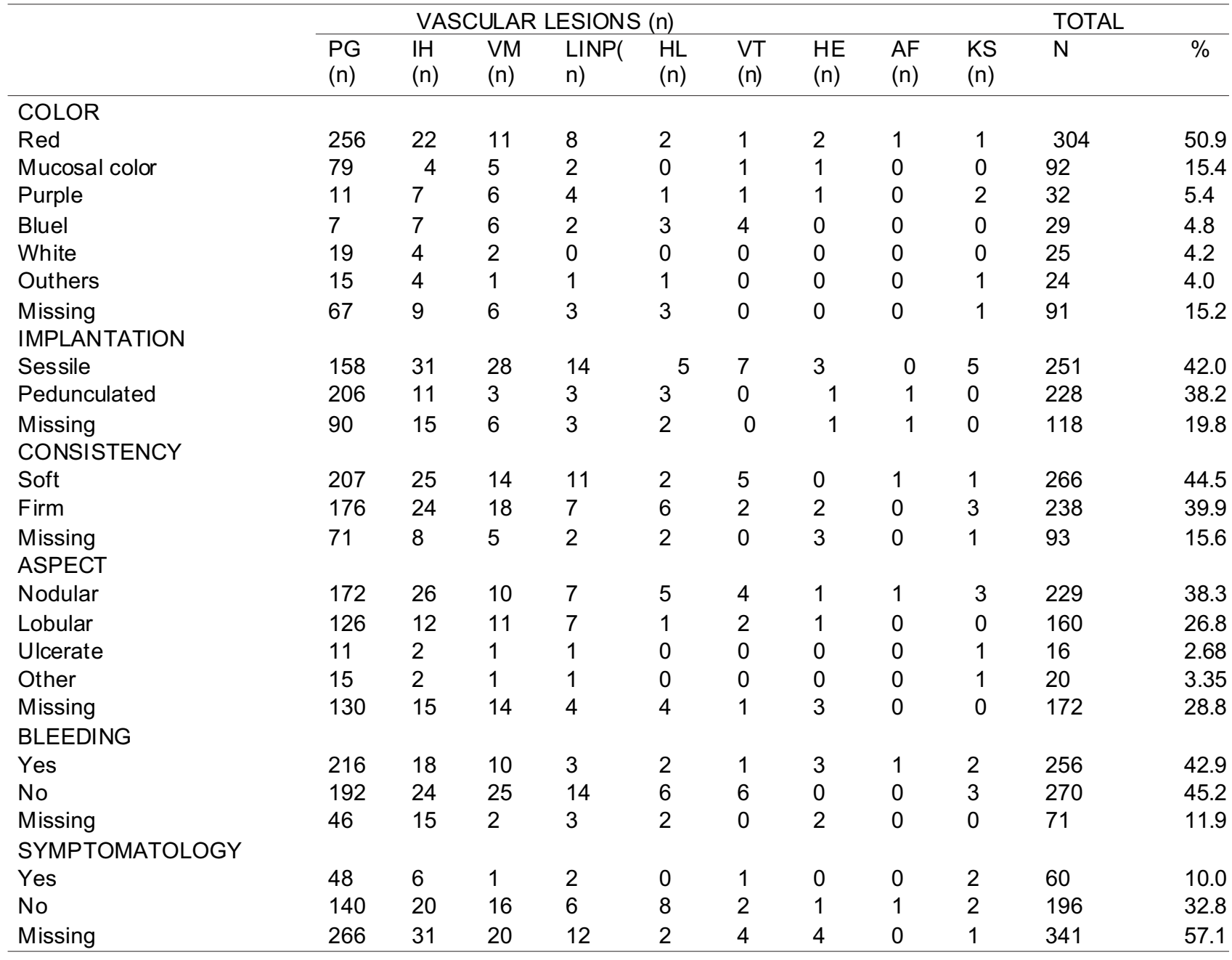

PG: Pyogenic granuloma; IH: Infantile hemangioma; VM: Vascular malformation; LINP: Lymphangioma; HL: Hemangiolymphangioma; VT: Vascular trombus; HE: Hemangioendothelioma; AF: Angiofibroma; KS: Kaposi sarcoma; Missing: lost cases; n: number of cases; \%: Percentage. 
Table V. Compatibility between clinical and e histopathological diagnoses of oral vascular anomalies das anomalies vascularesorais registered at the Service of Pathological Anatomy of the Department of Dentistry of the Federal University of Rio Grande do Norte, 2019.

\begin{tabular}{llllllllllll}
\hline & \multicolumn{4}{c}{ VASCULAR LESIONS (n) } & \multicolumn{4}{c}{ TOTAL } \\
& PG & IH & VM & LINP & HL & VT & HE & AF & KS & N & $\%$ \\
& $(n)$ & $(n)$ & $(n)$ & $(n)$ & $(n)$ & $(n)$ & $(n)$ & $(n)$ & $(n)$ & \\
\hline Vascular & 331 & 35 & 18 & 9 & 6 & 4 & 1 & 1 & 5 & 410 & 68.7 \\
Not vascular & 113 & 17 & 18 & 8 & 4 & 3 & 3 & 0 & 0 & 167 & 27.9 \\
Compatible & 324 & 21 & 1 & 2 & 0 & 1 & 0 & 0 & 4 & 353 & 59.1 \\
Not compatible & 120 & 31 & 35 & 15 & 10 & 6 & 4 & 1 & 1 & 224 & 37.5 \\
Missing & 10 & 5 & 1 & 3 & 0 & 0 & 2 & 0 & 0 & 20 & 3.4 \\
\hline
\end{tabular}

PG: Pyogenic granuloma; IH: Infantile hemangioma; VM: Vascular malformation; LINP: Lymphangioma; HL: Hemangiolymphangioma; VT: Vascular trombus; HE: Hemangioendothelioma; AF: Angiofibroma; KS: Kaposi sar

A 46-Year Retrospective Study of Oral Vascular Ano

Because the Oral Pathology Service of the Department of Dentistry of Federal University of Rio Grande do Norte receives biopsy specimens from many cities in the state of Rio Grande do Norte and only a few of them are collected from the clinics of the Department of Dentistry of Federal University of Rio Grande do Norte, some data could not be obtained due to incomplete documentation in the medical records. The number of cases without clinical data is shown in the tables for each category analyzed.

\section{DISCUSSION}

Epidemiological studies on VAs are sparse and the regular classification standard is rarely used. Therefore, the diagnosis of VAs becomes a challenge and professionals' knowledge about the particularities of each lesion is important to indicate the appropriate treatment. We used the nomenclature proposed by the ISSVA, which defines vascular tumors (benign and malignant) as a proliferation of endothelial cells, while VMs have a quiescent endothelium and are considered errors of vascular morphogenesis, probably resulting from mutations in the pathways that regulate embryogenesis and vasculogenesis (Enjolras et al.; Hassanein et al.; ISSVA Classification of Vascular Anomalies).

In the present study that comprised the longest period and included the largest number of cases of VAs published for a Brazilian population, PG was the most common lesion in the clinical charts registered at our service (454 cases). PG is a non-neoplastic benign proliferative lesion that develops in response to chronic local trauma, poor oral hygiene, hormonal factors, or cytogenetic anomalies (Jafarzadeh et al.,
2006; Tolentino \& Tolentino, 2009; Shaikh et al., 2012; Hunasgi et al., 2017). Studies have shown that PG generally affects white female patients in their second, third or fourth decade of life (Hunasgi et al.; AlKhateeb \& Ababneh, 2003; Saravana, 2009), in agreement with the present data. Regarding clinical features, our findings agree with the report of Martins et al. These authors describe PG as a sessile or pedunculated, lobulated or ulcerated nodule of soft or firm consistency whose color ranges from deep red to reddish-purple. The lesion is mainly found in the gingiva and is generally painless. Spontaneous bleeding or in response to minor trauma can be observed. The lips, tongue, cheek mucosa, and palate are other sites commonly affected by PG (Kamala et al., 2013; Neville et al., 2016).

The second most diagnosed disease was $\mathrm{IH}$ (57 cases). According to the literature reviewed, this vascular tumor is more common in infants and is characterized by the abnormal proliferation of endothelial cells and the formation of numerous blood vessels. Infantile hemangiomas appear shortly after birth, proliferate and undergo prolonged involution, completely disappearing or persisting as a residual lesion in adult life. These tumors are more frequent in white patients and preterm infants. The progressive growth of IH can cause local injuries characterized by pain, ulcerations and unexpected bleeding (Spiteri Cornish \& Reddy, 2001; Hemangioma Investigator Group et al., 2007; Habif, 2009; Johan et al.; Ballah et al., 2011; Amrock \& Weitzman, 2013). These features were also identified in the records analyzed in the present study. The number of $\mathrm{IH}$ found in this study is very low considering that this lesion is one of the most common lesions in infants. This data could be justified for the fact that there is no need of biopsy for the diagnosis. Also, the Service uses the GLUT-1 
COSTA, U.; GONZAGA, A. K. G.; OLIVEIRA, D. H. I. P.; SILVA FILHO, T. J. \& QUEIROZ, L. M. G. A 46-year retrospective study of oral vascular anomalies in a Brazilian population. Int. J. Odontostomat., 15(1):248-255, 202

positivity for diagnosis confirmation (de Oliveira et al., 2014; da Silva Filho et al., 2015, 2017), which decreases the number of lesions misdiagnosed as IHs.

Clinical presentation of $\mathrm{IH}$ varies according to size, affected site, depth, and evolution of the tumor. Superficial IHs appear as bright red, firm and welldelimited nodules or plaques, while deep tumors are nodular and have a mucosal or bluish color, in agreement with the peculiarities observed in the present study (Johann et al., 2005; Abdyli et al., 2016).

In an epidemiological study, Corrêa et al. (2007) found a higher prevalence of $\mathrm{IH}$ among females. On the other hand, no significant sex predilection was observed in the present study. In addition, IH was generally asymptomatic and mainly located in the lips, tongue, oral mucosa and palate, corroborating literature data (Corrêa et al.; Janmohamed et al., 2015).

In contrast to $\mathrm{IH}, \mathrm{VMs}$ are always present at birth, do not proliferate or involute, and persist throughout life, growing proportionally with the individual. Vascular malformations can be subdivided according to blood flow and the affected vascular components, and thus exhibit variable characteristics often analogous to those of $\mathrm{IH}$. In agreement with the present results, VMs exhibit a variable color and can be associated or not with pain. Esthetic alterations and local complications (ulceration and recurrent bleeding) have been reported (Kang \& Song, 2008; Abramowicz \& Padwa, 2012; Neville et al.; da Silva Filho et al., 2017).

Another vascular disease identified was lymphangioma, which is defined as a hamartomatous tumor of lymphatic vessels. The etiology is unknown and the tumor mainly occurs in children under 2 years of age and males (Neville et al.; Patel \& Sciubba, 2003; Vasconcelos et al., 2011). In contrast, in the present study, most lymphangiomaswere observed in adult women. Clinically, lymphangiomas appear as a painless stony nodular swelling of pink, red, purple or bluish color. The most commonly affected site is the tongue, followed by the lip (Aciole et al., 2010; Martins-Filho et al., 2011). These features were also observed in the present study, except that the lip was more affected.

This study identified a small number of cases of hemangiolymphangioma, vascular thrombus, hemangioendothelioma and angiofibroma, which are rare benign disorders. Published reports on these vascular diseases are limited, a fact further highlighting the importance of the present study. In agreement with our database, studies have shown a preference of these tumors for the gingiva, tongue, cheek mucosa, and palate (Manjunatha et al., 2009; Gordón-Núñez et al., 2010b).

The malignant vascular tumor detected was only one case of angiosarcoma and the borderline vascular tumors were Kaposi sarcomas. The first is a highly uncommon neoplasm that affects both sexes and has no specific age predilection (Robbins \& Cotran, 1988). Since there was only one case of angiosarcoma in our sample, no significant comparisons with the literature were possible. On the other hand, Kaposi sarcoma is a borderline neoplasm of endothelial cells most commonly diagnosed in adult men. The tumor clinically appears as multiple red to purple nodules frequently affecting the lip, as also observed in the present study (Ohe et al., 2010; de la Torre Navarro \& Gómez, 2010; Neville et al.).

No case of VAs associated to syndromes was found. This data can be explained by the fact that the Oral Pathology Service mostly receives intraoral and lip cases diagnosed for Dentistry clinicians. We believe that the syndrome cases could be diagnosed by general or vascular doctors and sent to general pathology laboratories.

Errors in the clinical diagnostic hypothesis suggested by the dentists who performed the biopsy were found in 224 cases, a considerably large number, with 167 cases being considered nonvascular alterations. In addition, many records were incomplete. It is important to point out that detailed documentation facilitates the correct diagnosis and, consequently, the adherence to appropriate treatment protocols.

The treatment of VAs has a wide range of possibilities, varying from only follow-up to invasive surgical. Procedures such as laser therapy, cryotherapy, electro cauterization, corticosteroids, administration of sclerosing agents, and embolization have also been reported in the literature (Johann et al.; Choi et al., 2016; Loureiro et al., 2010). It is important that the clinician is able to identify these lesions since the indicated treatment for some of them is only follow-up and an erroneous diagnosis can result in iatrogenic events or unnecessary mutilations. 


\section{CONCLUSION}

Oral VAs are distinct entities which, however, can exhibit similar clinical and histopathological features. Lack of consensus among professionals on the diagnosis and appropriate therapeutic management is therefore common. Within this context, acquiring knowledge about the clinical and demographic particularities of VAs and the correct use of the nomenclature created by the ISSVA will contribute to distinguish tumors that require invasive surgical treatment from spontaneously regressing tumors that only need adequate follow-up, thus preventing the use of expensive treatments or those that are potentially harmful to the patient.

COSTA, U.; GONZAGA, A. K. G.; OLIVEIRA, D. H. I. P.; SILVA FILHO, T. J. \& QUEIROZ, L. M. G. Estudio retrospectivo de 46 años de anomalías vasculares orales en una población brasileña. Int. J. Odontostomat. 15(1):248-255, 2021.

RESUMEN: Se realizó un estudio retrospectivo para describir las características demográficas y clínico-patológicas de casos de anomalías vasculares en una población brasileña. Los datos de los casos diagnosticados como anomalías vasculares durante un período de 46 años, fueron obtenidos de los archivos del Servicio de Anatomía Patológica del Departamento de Odontología de la Universidade Federal de Rio Grande do Norte. Se analizó la información de sexo, edad, raza, diagnóstico, ubicación y características clínicas, y se creó una base de datos para análisis en el sistema SPSS y descripción de los resultados. La muestra consistió de 597 casos categorizados de la siguiente manera: granuloma piógeno $(n=454)$, hemangioma infantil $(n=57)$, malformación vascular $(n=$ $37)$, linfangioma $(n=20)$, hemangiolinfangioma $(n=10)$, trombo vascular $(n=7)$, hemangioendotelioma $(n=5)$, angiofibroma $(n=1)$, hemangioendoteliosarcoma $(n=1)$ y sarcoma de Kaposi $(n=5)$. En general predominaron las mujeres de raza blanca $(64,2 \%),(54,2 \%)$, y pacientes en la $3^{\mathrm{a}}$ y $4^{\mathrm{a}}$ década de la vida. La mayoría de los casos afectaban la encía / cresta $(44,75 \%)$, tenían un color rojo / rojizo $(60,07 \%)$, implantación sésil $(52,4 \%)$, consistencia blanda $(52,7 \%)$ y apariencia nodular $(53,9 \%)$, no hemorrágicos $(51,3 \%)$ y asintomáticos $(76,6 \%)$. Los hallazgos demográficos y clínico-patológicos de la mayoría de las lesiones vasculares analizadas son similares a los reportados en la literatura de otras poblaciones. El conocimiento de las particularidades de estos trastornos es importante para el diagnóstico y la decisión de tratamientos adecuados.

PALABRAS CLAVE: anomalías vasculares, hemangioma, epidemiología.

\section{REFERENCES}

Abdyli, R. A.; Abdyli, Y.; Perjuci, F.; Gashi, A.; Agani, Z. \& Ahmedi, J. Sclerotherapy of intraoral superficial hemangioma. Case Rep. Dent., 2016:4320102, 2016.

Abramowicz, S. \& Padwa, B. L. Vascular anomalies in children. Oral Maxillofac. Surg. Clin. North Am., 24(3):443-55, 2012.

Aciole, G. T. S.; Aciole, J. M. S.; Soares, L. G. P.; Santos, N. R. S.; Santos, J. N. S. \& Pinheiro, A. L. B. Surgical treatment of oral lymphangiomas with $\mathrm{CO} 2$ laser: report of two uncommon cases. Braz. Dent. J., 21(4):365-9, 2010.

Al-Khateeb, T. \& Ababneh, K. Oral pyogenic granuloma in Jordanians: a retrospective analysis of 108 cases. J. Oral Maxillofac. Surg., 61(11):1285-8, 2003.

Amrock, S. M. \& Weitzman, M. Diverging racial trends in neonatal infantile hemangioma diagnoses, 1979-2006. Pediatr. Dermatol., 30(4):493-4, 2013.

Ballah, D.; Cahill, A. M.; Fontalvo, L.; Yan, A.; Treat, J.; Low, D. \& Epelman, M. Vascular anomalies: what they are, how to diagnose them, and how to treat them. Curr. Probl. Diagn. Radiol., 40(6):233-47, 2011.

Choi, B. E.; Kim, Y.; Leem, D. H.; Baek, J. A. \& Ko, S. O. Utility of sodium tetradecyl sulfate sclerotherapy from benign oral vascular lesion. Maxillofac. Plast. Reconstr. Surg., 38(1):44, 2016.

Corrêa, P. H.; Nunes, L. C. C.; Johann, A. C. B. R.; de Aguiar, M. C. F.; Gomez, R. S. \& Mesquita, R. A. Prevalence of oral hemangioma, vascular malformation and varix in a Brazilian population. Braz. Oral Res., 21(1):40-5, 2007.

da Silva Filho, T. J.; de Oliveira, D. H. I. P.; Brasil, V. L. M.; Nonaka, C. F. W.; da Silveira, E. J. D. \& Queiroz, L. M. G. An update of 77 cases diagnosed as oral hemangiomas based on GLUT-1 positivity. Exp. Mol. Pathol., 103(1):9-13, 2017.

da Silva Filho, T. J.; de Oliveira, D. H. I. P.; Moura, I. S.; da Silva Medeiros, L. K.; Gonzaga, A. K. G.; Brasil, V. L. M. \& Queiroz, L. M. G. Importância da GLUT1 no diagnóstico diferencial das anomalias vasculares. J. Vasc. Bras., 14(2):168-76, 2015.

de la Torre Navarro, L. M. \& Gómez, J. D. Sarcoma de Kaposi. Una revision. Rev. Haban. Cienc. Méd., 9(4):525-33, 2010.

de Oliveira, D. H. I. P.; da Silveira, E. J. D.; de Medeiros, A. M. C.; Alves, P. M. \& Queiroz, L. M. G. Study of the etiopathogenesis and differential diagnosis of oral vascular lesions by immunoexpression of GLUT-1 and HIF-1a. J. Oral Pathol. Med., 43(1):76-80, 2014.

Enjolras, O.; Wassef, M. \& Chapot, R. Color Atlas of Vascular Tumors and Vascular Malformations: Introduction: ISSVA classification. New York, Cambridge University Press, 2007. pp.1-11.

Gordón-Núñez, M. A.; de Vasconcelos Carvalho, M.; Benevenuto, T. G.; Lopes, M. F. F.; Silva, L. M. M. \& Galvão, H. C. Oral pyogenic granuloma: a retrospective analysis of 293 cases in a Brazilian population. J. Oral Maxillofac. Surg., 68(9):2185-8, 2010a.

Gordón-Núñez, M. A.; Silva, E. M. M.; Lopes, M. F. F.; de OliveiraNeto, S. F.; Maia, A. P. \& Galvão, H. C. Intraoral epithelioid hemangioendothelioma: a case report and review of the literature. Med. Oral Patol. Oral Cir. Bucal, 15(2):e340-6, 2010b.

Habif, T. P. Vascular Tumors and Malformations. Clinical Dermatology. $5^{\text {th }}$ ed. St. Louis (MO), Mosby Elsevier, 2009. pp.21-3.

Hassanein, A. H.; Mulliken, J. B.; Fishman, S. J. \& Greene, A. K. Evaluation of terminology for vascular anomalies in current literature. Plast. Reconstr. Surg., 137(1):347-51, 2011.

Hemangioma Investigator Group; Haggstrom, A. N.; Drolet, B. A.; Baselga, E.; Chamlin, S. L.; Garzon, M. C.; Horii, K. A.; Lucky, A. W.; Mancini, A. J.; Metry. D. W.; et al. Prospective study of infantile hemangiomas: demographic, prenatal, and perinatal characteristics. J. Pediatr., 150(3):291-4, 2007. 
Hiraki, P. Y. \& Goldenberg, D. C. Diagnosis and treatment of infantile hemangioma. Rev. Bras. Cir. Plast., 25(2):388-97, 2010.

Hunasgi, S.; Koneru, A.; Vanishree, M. \& Manvikar, V. Assessment of reactive gingival lesions of oral cavity: A histopathological study. J. Oral Maxillofac. Pathol., 21(1):180, 2017.

ISSVA Classification of Vascular Anomalies. International Society for the Study of Vascular Anomalies, 2018. Available from: https:/ /www.issva.org/classification

Jafarzadeh, H.; Sanatkhani, M. \& Mohtasham, N. Oral pyogenic granuloma: a review. J. Oral Sci., 48(4):167-75, 2006.

Janmohamed, S. R.; Madern, G. C.; de Laat, P. C. J. \& Oranje, A. P. Educational paper: Pathogenesis of infantile haemangioma, an update 2014 (part I). Eur. J. Pediatr., 174(1):97-103, 2015.

Johann, A. C. B. R.; Aguiar, M. C. F.; do Carmo, M. A. V.; Gomez, R. S.; Castro, W. H. \& Mesquita, R. A. Sclerotherapy of benign oral vascular lesion with ethanolamine oleate: an open clinical trial with 30 lesions. Oral Surg. Oral Med. Oral Pathol. Oral Radiol. Endod., 100(5):579-84, 2005.

Kamala, K. A.; Ashok, L. \& Sujatha, G. P. Pyogenic granuloma on the upper labial mucosa: a case report. J. Clin. Diagn. Res., 7(6):1244-6, 2013.

Kang, G. C. W. \& Song, C. Forty-one cervicofacial vascular anomalies and their surgical treatment--retrospection and review. Ann. Acad. Med. Singap., 37(3):165-79, 2008.

Loureiro, C. C. S.; Falchet, P. C. F.; Gavranich Jr., J. \& Leandro, L. F. L. Embolization as the treatment for a life-threatening mandibular arteriovenous malformation. J. Craniofac. Surg., 21(2):380-2, 2010.

Manjunatha, B. S.; Kumar, G. S. \& Vandana, R. Intraoral epithelioid hemangioendothelioma: an intermediate vascular tumor- a case report. Dent. Res. J. (Isfahan), 6(2):99-102, 2009.

Martins-Filho, P. R. S.; Piva, M. R.; Da Silva, L. C. F.; Reinheimer, D. M. \& Santos, T. S. Aggressive pregnancy tumor (pyogenic granuloma) with extensive alveolar bone loss mimicking a malignant tumor: case report and review of literature. Int. J. Morphol., 29(1):164-7, 2011.

Mulliken, J. B. \& Glowacki, J. Hemangiomas and vascular malformations in infants and children: a classification based on endothelial characteristics. Plast. Reconstr. Surg., 69(3):412-22, 1982.

Neville, B. W.; Damm, D. D.; Allen, C. M. \& Chi, A. C. Patologia Oral e Maxilofacial. $4^{\text {th }}$ ed. Rio de Janeiro, Elsevier, 2016.

Ohe, E. M. D. N.; Padilha, M. H. V. Q.; Enokihara, M. M. S. S.; de Almeida, F. A. \& Porro, A. M. Fatal outcome in classic Kaposi's sarcoma. An. Bras. Dermatol., 85(3):375-9, 2010.

Patel, N. J. \& Sciubba, J. Oral lesions in young children. Pediatr. Clin. North Am., 50(2):469-86, 2003.

Robbins, S. L. \& Cotran, R. S. Tumores de Malignidad Incierta: Hemangioendotelioma. En: Robbins. Patología Estructural y Funcional. 3rd ed. La Habana, Edición Revolucionaria, 1988.

Saravana, G. H. L. Oral pyogenic granuloma: a review of 137 cases. Br. J. Oral Maxillofac. Surg., 47(4):318-9, 2009.

Shaikh, S.; Singh, G.; Singh, A. \& Gaur, A. Pyogenic granuloma of unusual size with alveolar resorption in a 75-year-old patient. Natl. J. Maxillofac. Surg., 3(1):75-9, 2012.

Spiteri Cornish, K. \& Reddy, A. R. The use of propranolol in the management of periocular capillary haemangioma--a systematic review. Eye (Lond.), 25(10):1277-83, 2001.

Tolentino, E. S. \& Tolentino, L. S. Recurrent intraoral pyogenic granuloma: case report. Odontol. Clin. Cient., 8:263-7, 2009.

Vasconcelos, M. G.; Santos, B. C.;Lemos, L. C. P.; Ribeiro, B. F.; Iglesias, D. P. P.; Vasconcelos, R. G. \& de Medeiros, A. M. C. Oral lymphangiomas: case report. RSBO, 8(3):352-6, 2011.
Corresponding author:

Úrsula Costa

Departamento de Odontologia

Universidade Federal do Rio Grande do Norte

Av. Senador Salgado Filho 1787

Lagoa Nova, Natal - RN

CEP 59056-000

BRAZIL

E-mail: ursula_costa31@hotmail.com 